\title{
Implications of Japanese Universities Teaching Reform on Chinese University Education System Reform in the New Era
}

\author{
Lili Dong ${ }^{1, a}$ \\ ${ }^{1}$ College of Foreign Language, Jilin Agricultural University, Jilin, Changchun, China, 130118 \\ ${ }^{a}$ email,
}

Keywords: Implications, Japanese Universities Teaching Reform, Chinese University Education System, Reform, New Era

\begin{abstract}
In today's world, higher education has become an important force to promote the progress of the country and it is an important indicator of overall strength and international competitiveness, but also the basis for the country's soft power. In 21 century, even the economy of Japan is highly developed, it still continues to seek reform of university education and proposed new direction of its development. There are still many problems of university education in China at present, so exploring the Japanese university education reform direction in new era has an important inspiration and reference to our university education reform.
\end{abstract}

\section{Introduction}

The modernization of higher education in Japan began in the Meiji Restoration. After a half century of development, now Japan's higher education has entered the popular stage. Japan's higher education institutions can be divided into four types: university, junior college, College and Training School. According to the 1991 "School Basic Survey breaking news" statistics, Japan's current "507 University, where 97 national universities, 39 public, private 372; junior college has 593, including 41 national, 54 public, private 498; College 62, in which the National 54, four public and private four; Training school 2731, 170 public and private higher education by 2408 the total number of education 598. 10,000, of which 1.989 million college students, graduate students 90,000 junior college students to 473,000, 1.9 Higher Training school students, school students specializing in all kinds of 3.41 million. "

\section{Re-Awareness on the Nature of Education}

Plato once said, "Education is the soul to"; Comenius said, "education is to cultivate the harmonious development of man"; Dewey said, "Education is life, that is the growth of education, education is the experience of transformation and restructuring"; Spencer "Education is our perfect preparation for life" fundamentally, the essence of education is to promote the healthy growth of the individual human life, individual life to achieve a high degree of conversion to the community by the natural person. So as the essence of university education is nothing more than cultivate a sound personality and enrich the basic cultural knowledge, but also with "professional" education to Social ago. So university education shouldered function evolved into education students to master knowledge and skills to cope with life in the workplace after graduation, to improve the quality of life, promote social development, so as to promote the cultural heritage of society as a whole, and the whole nation. I believe that education is the core of how to improve the training model, creating social applications talents for qualified vocational education.

\section{The Status Analysis of Chinese University Education}

Starting from our university education, we can reflect on the basic problem of the existence of university education.

First, the overall level of China's school current presence is not high. From an international point of view, our universities no one can enter the top 100 university international ranking, the best 
Peking University, Tsinghua University was only just entering 200. With the increasing of China's international status, it seriously hampered the social influence of our country, affecting the culture of cutting-edge talents and technological power to limit us to become a dream comes true. As a result of China's international status also presents new challenges, as the current reform of higher education must consider the question of how to cultivate high-quality personnel.

Second, the current size of China's university continues to expand, the number of students receiving university education is growing, but the school management, teachers and many other factors cannot keep pace with the rapid development of the school to make the school into a chaotic era.

Third, the serious consequences of the education industrialization have led to retreat into the school age, the level of management behind. School to make money, to name to Lee; teacher for a book, write papers, to go out to earn money; students are doing nothing, basically entering into college relaxation phase.

Finally, the school is not reasonable professional setting, wasting a lot of educational resources, there is a big university and the lack of ideas and strengthen effective measures. School graduates lack practical skills into the community and lack of convergence with the actual operation.

\section{The Background of Japanese University Education Reform}

Throughout the 1980s, the rapid growth of the world's scientific and technological achievements, usually every 7--10 years, knowledge is twofold increase equivalent to an annual growth rate of new knowledge $7 \%-10 \% .80$ years later, the information industry average annual growth rate in developed countries more than 15\%, the growth rate of the information industry than GNP growth rate eight times, also in traditional industries and information technology. However, the Japanese tradition of higher education with respect to the rapid development of information society, show a clear lag, the urgent need for reform.

As we all know, Japanese society known as known as "diploma society" in. The so-called educated society, education level refers to a person based on his final graduate school degree may be, according to this "academic" social rank among their lifetime is located. Compared with the feudal society of the hereditary system, emphasis on education is undoubtedly a big step forward in Japanese society. However, ignoring people's actual ability and emphasis on education, gave Japanese society bring a lot of side effects, mainly in the following two aspects: First, different qualifications, different of their status in society, education on wages, choice of occupation, spouse has a significant impact, causing people to achieve higher education and struggle. Of long-term school education and people tend to over-reliance on the examination of competition also contributed to the degree of social disadvantages. Second, the same college graduates do not necessarily get the same working conditions. Graduates of prestigious universities is easy to find a good job, you can get more promotion opportunities. In addition, large enterprises, "designated schools recruitment system", as well as central government officials uses a specific focus on upgrading university also contributed to the degree of emphasis on wind society.

Despite the popularity of higher education in Japan and Europe and other countries comparable, even more than the development of Europe, but Japan's contribution to the world of higher education and technological progress is far lower than in Europe and America, but also less in the international academic exchanges, which Japanese scale of higher education is not consistent. In 1984 the Japanese Prime Minister Nakasone at the beginning of his proposed reform of higher education as that is one of the three policy governance, and set up a "provisional Council for Education," for future reforms necessary review and guidance.

\section{The Contents of Japanese University Education Reform}

Promote the Reorganization and Merger of National University. According to the trend of Japan's current severe economic, financial and legal situation of the development of the university to strengthen the management infrastructure, and promote greater development of the university, 
requires the flexibility to advance boldly between the University reorganized, merged. Yamanashi University, University of Tsukuba and University Library and Information has started to establish a new university matters a positive and concrete discussions, school heads around the future development of the university, how unique and how to enhance the overall strength of the institutions of higher learning and how to adapt to nationals needs and expectations, and other related topics on the restructuring and consolidation of the University presented a positive and effective suggestions and comments, the State Ministry of Education will be based on these suggestions and comments, and ultimately develop a specific program of reforms in the country.

Deepen the Reform of Higher Education Content and Curriculum. In educational content and curriculum, in order to meet the needs of economic and social development of the student's personality, the Japanese university education propylene capacity further specialization and integration, and expand the range of elective students, according to socio-economic development of the talent necessary to develop a comprehensive. Before 1991, the state not only provides graduates the necessary credits (124 credits or more), but also details the various courses required for their credits. Through reform, now only provides the basic criteria set required for graduation 124 total credits, no longer subject to the provisions of distinction corresponding credits to this permission to the university, in 1996 already 80\% of the university setting new benchmarks in accordance with the spirit of the university education curriculum restructuring; no longer the course is divided into parenting education and specialized education, but to build a consistent system of four-year curriculum, relying on the strength of all the faculties of education to enrich education.

The Development Model Establishment of the Integration of Production, Learning and Research. In order to further expand opening up the National University to society, the government has increased the funding for scientific research at the University of inputs, and to encourage large enterprise groups and universities to establish a joint research center. Continue to strengthen the working population regression and distance education, the creation of various forms of degree-granting institutions. To enrich and strengthen the Graduate School of Education: both in quality and quantity to further enrich the Graduate School of Education, in 1995, the Graduate School of Japanese development in the number of students in 1990 90,238 people to 153,423 people.

Further Expand International Exchanges and Cooperation. The implementation of mutual recognition of credits, qualifications, degrees with foreign institutions of higher learning, to promote the internationalization of higher education institutions, to strengthen the extensive international exchanges, international joint research to increase efforts to accept foreign students and foreign teachers and researchers. On the one hand is the Japanese students through short-term study abroad for a year to strengthen international exchanges and, on the other hand is full of teaching foreign students studying in Japan, not only enrich students studying in Japan for the Japanese and educational situation in Japan, but also to carry out university with the teaching of Foreign Languages.

Promote Higher Education is Opening to the Public. Higher Education in Japan to open to the public in two ways: First, the University offers public lectures. Public lectures can expand award surface, promoting universal education higher education; university research can be directly applied in practice; and work can guide the young people to study science and technical knowledge, it is conducive to employment, but also conducive to social stability. Second, universities and junior colleges offer evening division and Correspondence Department. Japanese universities order to provide our youth employment and work opportunities for the public higher education, the creation of the Department of the night and the Correspondence Department. However, they learn different purposes, most of them in order to obtain specific qualifications or qualifications, followed in order to obtain the knowledge and skills necessary for the work, or for the pursuit of fun, become educated people.

\section{The Inspiration of Japanese University Education Reform for China}

University education has long been considered fundamental vocational education. In the new 
century, Japan converted this basic idea, put forward the concept of lifelong learning, students focus on personal qualities improve and strengthen the development of personal skills, enhance the concept of national and international perspective, the establishment of research, independent university. Meanwhile, Japan pursued by professors in universities and students explore learning methods, too, we can learn from.

Japanese Central Council for Education will be on (School Education Act) amended the proposed implementation of university, graduate school admission of flexible, on the school system to focus on school selection, admission, personnel evaluation system three "diversity" and the establishment of universities, support system between the School. As we all know, Japan has always been a technology innovation Nation as the goal, focus on basic research and to improve the technical sophistication, which is reflected in the 21 century Japanese education reform goals is particularly evident in the establishment of national universities objectives focus on research height of School and diversification; improve State University system operators; establish pluralistic evaluation system; actively promote student exchange, academic research, carried out a comprehensive scientific and technological research; promote industry-academia joint research activated. Make these objectives actively promote the reform of national universities, no doubt on Japan's educational innovation, education innovation, education and power played a very good role in the guidelines.

We all know that in education in Japanese universities teachers, teachers with practical experience occupy a large proportion of this part of the teacher's experience is the greatest wealth. Practice makes perfect truth reflected most vividly in the Japanese university education, but also increased the importance of education itself is the strong social practice. Japan can catch up in the mid-sixties to Germany, and then become the second largest economy after the United States and this is thanks to this. Of course, this problem cannot be excluded ethnic nation Japan and Japan, to national prosperity in the Japanese concept of the responsibility of the nation who can show up anywhere. Moreover, China's university teachers in this regard, the Japanese apparently there are some differences. Not strong sense of responsibility as a teacher, as a social problem in recent years, it has repeatedly been mentioned, which have caused people to think deeply. Country road in the development of continuous exploration, universities also have planned and purposeful training teachers, but these still need a strict examination system to strengthen this fundamental point, the instructor to create the conditions to ensure the basic quality of teaching at the same time, to study teaching methods tailored to the specific reality.

As Japan's economic power in the community proportion of educational resources, the implementation of strong measures, from the upper to the lower levels, from national to local, assign distinct functions at all levels, all levels of government agencies, universities are based on the national education policy actively development, respect for the autonomy of the university, and strengthen the spirit of community cooperation, and this forms a whole country atmosphere. This is available to people in terms of per capita greatly improved learning opportunities, but also in the improvement of educational resources, has been greatly satisfied. Our economy is not developed in Japan, the majority of the land area, at this point you want to learn from the successful experience of Japan, but also need to develop the national economy, to increase resources for basic education.

\section{Conclusion}

The core and essence of Japan got rapid development after World War II lies on developing education. Practical education system created a much-needed talent in a special historical period in Japan. In the peaceful development today, Japan still continues to seek a college education reform and put forward a new development direction. It has a lot of inspiration for our university education, while it has a profound significance for the international development of the times.

\section{References}

[1] Ma Mingyang. Japanese Higher education reform characteristics and inspiration[J]. Japanese 
Studies, 2002.1

[2] Fang Liqing. Japanese higher education reform enlightenment[J]. Journal of Fuzhou University, 2000.4

[3] Feng Xia. Japan's higher education reform and its Implications for our country [J] Guangxi Financial College Newspaper, 2001, 5

[4] Li Lifang. Inheritance and transcendence: education reform in the new university in Japan and hair development policy [J] Modern Education Management, 2012, 1

[5] Liu Minyi. Legislation and government promotion: Japanese research characteristics and Inspiration[J] Science Times, 2013, 1 